\title{
Breaking seed dormancy of Tulipa scardica Bornm. and Tulipa kosovarica Kit Tan, Shuka \& Krasniqi by pre-chilling, plant growth regulators and some chemical treatments
}

\author{
Bekim GASHI ${ }^{1}$, Mirsade OSMANI ${ }^{2,3}$, Sali ALIU ${ }^{4}$
}

Breaking seed dormancy of Tulipa scardica Bornm. and Tulipa kosovarica Kit Tan, Shuka \& Krasniqi by pre-chilling, plant growth regulators and some chemical treatments

Abstract: Tulipa scardica and T. kosovarica are rare, endemic and endangered plants in Kosovo. This research was carried out to study the dormancy breaking treatment in Tulipa scardica and T. kosovarica seeds by pre-chilling and various concentration of potassium nitrate $\left(\mathrm{KNO}_{3}\right)$, gibberellic acid $\left(\mathrm{GA}_{3}\right)$, kinetin, thiourea and sulfuric acid $\left(\mathrm{H}_{2} \mathrm{SO}_{4}\right)$. The experiment was conducted with untreated seeds (without stratification) and with stratified seeds ( 8 weeks) and treated with different concentration of some chemicals and plant growth regulators. Results showed that the final germination percentage (FGP) of seeds without stratification at both Tulipa plant species was zero, while germination was enhanced by pre-chilling (stratification) especially after treatment of these seeds by above mentioned treatments. Both Tulipa species showed an increase in mean germination time (MGT), an indication of slower germination, as different chemicals or plant growth regulators increased. Depending on treatments, germination was ranging from $80 \%$ to $90 \%$, the maximum germination was detected in seeds treated with $\mathrm{KNO}_{3}, \mathrm{GA}_{3}$, and their combination, while the minimum germination in seeds without treatments and treated with thiourea. The conservation of these plants in botanic gardens by cultivation or propagation for commercial use as ornamental plants could give an effective contribution to the conservation of these plants.

Key words: Tulipa scardica; Tulipa kosovarica; breaking seed dormancy; chemicals; hormones

Abbreviations: $\mathrm{KNO}_{3}$ - potassium nitrate; $\mathrm{GA}_{3}$ - gibberellic acid; $\mathrm{H}_{2} \mathrm{SO}_{4}$ - sulfuric acid; FGP - final germination percentage; MGT - mean germination time.
Received December 19, 2018; accepted April 01, 2019. Delo je prispelo 19. decembra 2018, sprejeto 01. aprila 2019.

Prekinitev dormance semen dveh vrst tulipanov (Tulipa scardica Bornm. in Tulipa kosovarica Kit Tan, Shuka \& Krasniqi) $s$ predhodnim hlajenjem, rastlinskimi rastnimi regulatorji in nekaterimi kemičnimi obravnavanji

Izvleček: Vrsti Tulipa scardica in T. kosovarica sta redki, endemični in ogroženi vrsti na Kosovu. Raziskava je bila opravljena za preučitev prekinitve dormance semen obeh vrst $\mathrm{s}$ predhodnim hlajenjem (stratifikacijo), z obravnavanji z različnimi koncentracijami kalijevega nitrata $\left(\mathrm{KNO}_{3}\right)$, giberelinske kisline $\left(\mathrm{GA}_{3}\right)$, kinetina, tiouree in žveplene kisline $\left(\mathrm{H}_{2} \mathrm{SO}_{4}\right)$. Poskus je bil narejen s stratificiranimi ( 8 tednov) in nestrastificiranimi semeni in $\mathrm{z}$ različnimi koncentracijami omenjenih kemikalij ter rastlinskih rastnih regulatorjev. Rezultati so pokazali, da je bil končni odstotek kalitve nestratificiranih semen (FGP) pri obeh vrstah ničen, kalitev stratificiranih semen pa je bila po zgoraj omenjenih obravnavanjih povečana. Obe vrsti sta pokazali povečanje $\mathrm{v}$ poprečnem času kalitve (MGT), kar kaže na upočasnjeno kalitev ob povečanju koncentracij uporabljenih kemikalij in rastlinskih rastnih regulatorjev. Odvisno od obravnavanja, je bila kalitev med $80 \%$ in $90 \%$, največja kalitev je bila ugotovljena pri semenih, ki so bila tretirana s $\mathrm{KNO}_{3}$ in $\mathrm{GA}_{3}$ $\mathrm{v}$ različnih kombinacijah, najmanjša kalitev je bila ugotovljena pri semenih, ki so bila tretirana s tioureo. Ohranjanje teh rastlin $\mathrm{z}$ gojenjem in razmnoževanjem $\mathrm{v}$ botaničnih vrtovih $\mathrm{v}$ komercialne namene kot okrasne rastline bi bil učinkovit prispevek $\mathrm{k}$ njihovi zaščiti v naravi.

Ključne besede: Tulipa scardica; Tulipa kosovarica; prekinitev dormance semen; kemikalije; hormoni

Okrajšave: $\mathrm{KNO}_{3}$ - kalijev nitrat; $\mathrm{GA}_{3}$ - giberelinska kislina; $\mathrm{H}_{2} \mathrm{SO}_{4}$ - žveplena kislina; FGP - končni odstotek kalitve; GT - srednji čas kalitve.

\footnotetext{
Department of Biology, Faculty of Mathematics and Natural Sciences, University of Pristina, Republic of Kosovo

2 Faculty of Food Technology, University of Mitrovica, Republic of Kosovo

3 Corresponding author, e-mail: mirsade.osmani@umib.net

4 Department of Crop Science, Faculty of Agriculturae, University of Pristina, Republic of Kosovo
} 


\section{NTRODUCTION}

The genus Tulipa in Kosovo is represented with five species: Tulipa kosovarica, T. luanica Millaku, T. serbica Tatić \& Krivošej, T. australis Link and T. scardica (Shuka et al., 2012; Millaku and Elezaj, 2015). T. kosovarica and T. scardica grow in serpentine soil, well-drained soil in full sun, sheltered from strong winds. Tulips can be propagated through bulbs or seeds, both of them have the dormancy due to a common biochemical mechanisms and even a common genetic control (Millaku and Elezaj, 2015; Osmani et al., 2018).

Seed dormancy is a mechanism by which seeds can block the completion of germination or inhibit their germination of an intact viable seed in order to wait for more favorable conditions (Finkelstein et al., 2008). However, this dormancy is also known as secondary dormancy, but the primary dormancy is caused by effects of abscisic acid (ABA) during seed development. This block to seed germination has been further negatively categorized, but this is the main mechanisms for establishing a new plant generation (Finkelstein et al., 2008). Seed dormancy by earlier reviews has been described as one of the least understood phenomena in seed biology (Finch-Savage and Leubner, 2006), perhaps because it is manifested and broken in different ways at different plant species. In the past decades, ecological and physiological studies have reported confusion theory for seed dormancy, but now is known that dormancy is not a single phenomenon but a condition with many contributing causes (Miransari and Smith, 2014). Among the most important parameters controlling the process of seed dormancy are changes at molecular levels, including the protein and hormonal alternations, and balance between ABA and gibberellins (GA) (Finch-Savage and Leubner, 2006; Finkelstein et al., 2008; Miransari and Smith, 2014). In seeds of a very few species, there are some external factors such as light, chilling, chemical or hormonal treatment, and internal factors such as hormonal balance, that can stimulate the germination, in this case to break down the seed dormancy (Miransari and Smith, 2014).

Gibberellins appear not to be involved to control seed dormancy but are important to activate dormant seed as well as in the promotion and enhance the germination (Miransari and Smith, 2014). GA and ABA activity is thought to be closely related, because ABA at few plant species can inhibit seed germination, while increase of the GA content stimulates their germination or are necessary for seed germination (Bewley, 1997; Miransari and Smith, 2014; Finkelstein et al., 2008). Nitrate $\left(\mathrm{NO}_{3}{ }^{-}\right)$and gibberellins are used for enhance seed germination as well as for breaking seed dormancy. $\mathrm{NO}_{3}{ }^{-}$ is like a source of $\mathrm{N}$, which enhances seed germination.
$\mathrm{N}$ compounds can play important role in germination through enhancing amylase activity, adjusting $\mathrm{K}^{+} / \mathrm{Na}^{+} \mathrm{ra}-$ tio, increasing the ATP production and also can inhibit seed dormancy by decreasing the level of ABA in the seed (Alboresi et al., 2005; Zheng et al., 2009; Finkelstein et al., 2008). $\mathrm{NO}_{3}^{-}$such as $\mathrm{KNO}_{3}$ has been found to stimulate the germination of dormant seeds (Alboresi et al., 2005). According to Association of Official Seed Analysts and the International Seed Testing Association, solutions of 0.1 to $0.2 \% \mathrm{KNO}_{3}$ are common in routine germination testing and are recommended for germination tests of many species (ISTA, 1996). However, plant hormones such as gibberellins and cytokinins can positively regulate the process of seed germination through negative interaction with ABA (Hermann et al., 2007). Biochemical reactions known to be enhanced by GA are activation of catabolyzing enzymes (nitrite and nitrate reductase and glutamine synthetase) and inhibition biosynthesis pathways of ABA. GA also stimulates seed germination via amylase synthesis (Finch-Savage and Leubner, 2006).

According to the Red Book and Red List of Vascular Flora of the Republic of Kosovo, T. kosovarica and T. scardica are categorised as "Critically Endangered" (CR) plant species (Millaku, 2013; KEPA, 2013). In this case, the conservation of these plants in botanic gardens by cultivation or propagation for commercial use as ornamental plants could be as an effective contribution to conservation of these plants. Therefore, the aim of this study was to determine the effects of different physical, chemical and hormonal treatments which are able to break seed dormancy and enhance germination of these important rare and endemic or ornamental plants.

\section{MATERIALS AND METHODS}

\subsection{SEED COLLECTION AND TREATMENTS}

The study was carried out with T. kosovarica seeds collected from native populations in the nearby of Mrasor village (Kosovo), and with T. scardica seeds collected in the nearby of Krevenik village (Kosovo). Seeds were cleaned and stored in paper bags in darkness at room temperature $\left(\sim 24^{\circ} \mathrm{C}\right)$ until the beginning of the experiments. After that, seeds were disinfected with ethanol $70 \%$ for three minutes and rinsed three times with distilled and sterilized water, before treatments.

For stratification treatment, seeds of both tulip species were mixed in perlite medium and distilled water in vessels, then transferred to refrigerator for 8 weeks at $5{ }^{\circ} \mathrm{C}$. These vessels were put into sealed plastic bags to avoid moisture loss. After this procedure, the seeds were rinsed with distilled water three times. After stratifica- 
tion, seeds were divided into seven treatment groups: 1) seeds of the first group were soaked in $\mathrm{H}_{2} \mathrm{O}$-distilled water (control); 2) seeds of the second group were treated by $0.1,0.2$ and $0.3 \%(\mathrm{v} / \mathrm{v})$ potassium nitrate $\left(\mathrm{KNO}_{3}\right)$ for $24 \mathrm{~h}$; 3) likewise, similar to the previous treatment, the seeds of the third group were put into flasks containing 250, 500 and 1000 ppm gibberellic acid (GA $)$ for $24 \mathrm{~h}$; 4) seeds of the fourth group were treated with combination of $\mathrm{GA}_{3}$ and $\mathrm{KNO}_{3}$ with previous describe concentration; 5) seeds of the fifth group were put into flasks containg 250, 500 and 1000 ppm 6-furfurylaminopurine (Kinetin); 6) seeds of the sixth group were treated with 0.5 molar (M) and $1 \mathrm{M}$ of thiourea; and 7) seeds of the seventh group were treated with $1 \%$ and $2 \%(\mathrm{v} / \mathrm{v}) \mathrm{H}_{2} \mathrm{SO}_{4}$ for 30 and 60 seconds, respectively. For all seeds groups, the experiment was conducted with four replicates of 25 seeds which were germinated on top of double layered papers (ISTA, 1996) with $5 \mathrm{ml}$ of water in $10 \mathrm{~cm}$ Petri dishes. These Petri dishes were placed into sealed plastic bags to avoid moisture loss. Seeds were allowed to germinate at $24 \pm 1{ }^{\circ} \mathrm{C}$ and at light regime $16 \mathrm{~h}$ light (day) $/ 8 \mathrm{~h}$ darkness (night).

\subsection{GERMINATION TESTS}

The germination percentage is an estimation of the viability of seeds. Germinated seeds were counted every $48 \mathrm{~h}$ for 40 days after first germination (the seeds had begun to germinate after the $30^{\text {th }}$ day). Germination was considered to have occurred when the seminal roots were $2 \mathrm{~mm}$ long. The following germination parameters were recorded:

1) Final germination percentage (FGP) is: FGP = (number of germinated seeds/number of total seeds) $\times$ 100.

2) Mean Germination Time (MGT) was calculated according to the following equation (Moradi et al., 2008).

$\mathrm{MGT}=\Sigma \mathrm{Dn} / \Sigma \mathrm{n}$

Where $\mathrm{n}$ is the number of seeds, which were germinated on day $\mathrm{D}$, and $\mathrm{D}$ is the number of days counted from the beginning of germination.

\subsection{STATISTICAL ANALYSIS}

The statistical analyses were of completely randomized design. Four replications and 25 seeds per replicate were used. The mean and one-way ANOVA were calculated using SPSS software. The means were compared using Duncan's multiple range tests at $5 \%$ level of probability and LSD test with the statistical significance set at P 0.01 and P 0.05 levels.

\section{RESULTS AND DISCUSSION}

Based on the obtained results during expeditions, T. scardica is an endemic plant and grows only in one population in Kosovo (520 m a.s.l. in Krivenik), and this population is very rare and fragmented with very lower density. On the other hand, T. kosovarica is a steno-endemic plant species of Kosovo, which is grown in some populations in central part of Kosovo (400 m a.s.l. in Mrasor; $620 \mathrm{~m}$ a.s.l in Goriq; and $700 \mathrm{~m}$ a.s.l. in Llapushnik), but these populations are very fragmented and with very low plant density as well as T. scardica. Both tulip species grow in serpentine soils and previous investigation reported that $T$. kosovarica grows in soil with a higher concentration of $\mathrm{Ni}, \mathrm{Mn}, \mathrm{Fe}, \mathrm{Cr}, \mathrm{Co}$ and $\mathrm{Cd}$, and lower concentration of $\mathrm{N}$ and Ca (Osmani et al., 2018). Moreover, some of these metals such as $\mathrm{Ni}, \mathrm{Mn}$ and $\mathrm{Fe}$ are bioaccumulated in plant organs and mostly in seeds of these species. In this case, we can presume that these metals can be involved in seed coat structure which directly contributes to resistance of these seeds in one hand, and in the metabolic pathway which can play a role as an ionic activator for enzyme during seed germination in another hand.

Analysis of variance for $F$ - values (Table 1) showed

Table 1: Analysis of variance for $\mathrm{F}$ - values of different treats on seed germination (FGP) and time of germination (MGT)

\begin{tabular}{|c|c|c|c|}
\hline \multicolumn{4}{|l|}{ T. scardica } \\
\hline SOV & $\mathrm{df}$ & FGP & MGT \\
\hline Gibberellin & 3 & $0.17^{\star}$ & $49.9^{* *}$ \\
\hline $\mathrm{KNO}_{3}$ & 3 & $0.86^{\mathrm{NS}}$ & $38.06^{* *}$ \\
\hline Kinetin & 3 & $0.37^{\mathrm{NS}}$ & $19.61^{\star *}$ \\
\hline Thiourea & 2 & $2.50^{\star *}$ & $2.11^{\mathrm{NS}}$ \\
\hline $\mathrm{H}_{2} \mathrm{SO}_{4}$ & 4 & $1.32^{\star \star}$ & $22.37^{\star *}$ \\
\hline Gibberellin ${ }^{*} \mathrm{KNO}_{3}$ & 9 & $31.89^{* *}$ & $17.90^{* *}$ \\
\hline \multicolumn{4}{|l|}{ T. kosovarica } \\
\hline Gibberellin & 3 & $15.95^{\star *}$ & $90.06^{* *}$ \\
\hline $\mathrm{KNO}_{3}$ & 3 & $15.20^{\star *}$ & $18.46^{\star *}$ \\
\hline Kinetin & 3 & $173.92^{* *}$ & $26.14^{\star *}$ \\
\hline Thiourea & 2 & $30.72^{* *}$ & $27.84^{\star *}$ \\
\hline $\mathrm{H}_{2} \mathrm{SO}_{4}$ & 4 & $13.78^{\star *}$ & $49.33^{\star *}$ \\
\hline Gibberellin ${ }^{*} \mathrm{KNO}_{3}$ & 9 & $39.92^{* *}$ & $4.12^{\star *}$ \\
\hline
\end{tabular}

* Significance for level of probability LSD $p=0.05$

** Significance for level of probability LSD $p=0.01$ 
that there are some significant differences between the same treatment in final germination percentage (FGP) and mean germination time (MGT) on seeds of T. scardica and T. kosovarica, especially for the double interaction effects of gibberellin and $\mathrm{KNO}_{3}$. Between different concentration of $\mathrm{KNO}_{3}$ and kinetin of $T$. scardica seeds no significant differences were shown.

The obtained results showed that the FGP of seeds without stratification at both tulip species was zero (Table 2). Seed germination of these species was enhanced by pre-chilling (stratification) especially after treatment of these seeds by different chemicals or plant growth regulators. Both Tulipa species showed an increased MGT, indicative of slower germination, as different chemicals or plant growth regulators increased. In this case, the slower germination time was founded in stratified seeds (control) of T. scardica compared with T. kosovarica (Table 2 and Figure 1). It seems that the seeds of these two tulip species are dormant and for breaking dormancy they need stratification with low temperature (pre-chilling) for 8 weeks. Similar results were reported in Tulipa kaufmanniana Regel, seeds of this species didn't germinate without pre-chilling, and after 5 or 7 weeks of stratification the germination rate was enhanced significantly (Rouhi et al., 2010). Acordding to Zhang et al. (2010), wild Tulipa gesneriana seed had deep dormancy phenomenon, and the dormancy could be absolved by low temperature and $\mathrm{GA}_{3}$ treatment. Stratification plays very important role to improve sensitivity for overcome dormancy and induce an increase in sensitivity to $\mathrm{GA}_{3}$

Table 2: Final germination percentage (FGP) and mean germination time (MGT) of seeds of T. scardica and T. kosovarica under various levels of $\mathrm{GA}_{3}$ (in ppm), $\mathrm{KNO}_{3}$ (in \%), kinetin (in ppm), thiourea (in $\mathrm{M}$ ) and $\mathrm{H}_{2} \mathrm{SO}_{4}$ (in \%)

\begin{tabular}{|c|c|c|c|c|}
\hline \multirow[b]{2}{*}{ Treatments } & \multicolumn{2}{|c|}{ T. scardica } & \multicolumn{2}{|c|}{ T. kosovarica } \\
\hline & FGP & MGT & FGP & MGT \\
\hline Control (without stratification) & - & - & - & - \\
\hline Control (with stratification) & $20.33^{\mathrm{EF}}$ & $61.00^{\circ}$ & $16.33^{\mathrm{J}}$ & $59.67^{\circ}$ \\
\hline $\mathrm{KNO}_{3}(0.1 \%)$ & $90.67^{\mathrm{A}}$ & $53.67^{\mathrm{MN}}$ & $83.00^{\mathrm{C}-\mathrm{F}}$ & $49.33^{\mathrm{LM}}$ \\
\hline $\mathrm{KNO}_{3}(0.2 \%)$ & $88.00^{\mathrm{AB}}$ & $46.67^{\mathrm{J}}$ & $81.67^{\mathrm{D}-\mathrm{F}}$ & $44.00^{\mathrm{JK}}$ \\
\hline $\mathrm{KNO}_{3}(0.3 \%)$ & $84.00^{\mathrm{AB}}$ & $55.33^{\mathrm{N}}$ & $79.67^{\mathrm{EF}}$ & $55.33^{\mathrm{N}}$ \\
\hline $\mathrm{GA}_{3}(250 \mathrm{ppm})$ & $77.33^{\mathrm{AB}}$ & $40.33^{\mathrm{GH}}$ & $84.33^{\mathrm{B}-\mathrm{F}}$ & $38.67^{\mathrm{E}-\mathrm{G}}$ \\
\hline $\mathrm{GA}_{3}(500 \mathrm{ppm})$ & $72.00^{\mathrm{A}-\mathrm{C}}$ & $41.33^{\mathrm{GH}}$ & $88.00^{\mathrm{A}-\mathrm{E}}$ & $40.33^{\mathrm{G}-\mathrm{I}}$ \\
\hline $\mathrm{GA}_{3}(1000 \mathrm{ppm})$ & $68.00^{\mathrm{A}-\mathrm{D}}$ & $50.33^{\mathrm{KL}}$ & $76.00^{\mathrm{F}}$ & $51.67^{\mathrm{M}}$ \\
\hline $\mathrm{GA}_{3}(250 \mathrm{ppm})+\mathrm{KNO}_{3}(0.1 \%)$ & $86.67^{\mathrm{AB}}$ & $36.67^{\mathrm{D}-\mathrm{F}}$ & $91.00^{\mathrm{A}-\mathrm{C}}$ & $36.00^{\mathrm{C}-\mathrm{E}}$ \\
\hline $\mathrm{GA}_{3}(250 \mathrm{ppm})+\mathrm{KNO}_{3}(0.2 \%)$ & $80.00^{\mathrm{AB}}$ & $33.33^{\mathrm{BC}}$ & $92.33^{\mathrm{AB}}$ & $34.33^{\mathrm{B}-\mathrm{D}}$ \\
\hline $\mathrm{GA}_{3}(250 \mathrm{ppm})+\mathrm{KNO}_{3}(0.3 \%)$ & $92.00^{\mathrm{A}}$ & $35.00^{\mathrm{C}-\mathrm{E}}$ & $92.87^{\mathrm{AB}}$ & $35.00^{\mathrm{B}-\mathrm{D}}$ \\
\hline $\mathrm{GA}_{3}(500 \mathrm{ppm})+\mathrm{KNO}_{3}(0.1 \%)$ & $84.00^{\mathrm{AB}}$ & $30.33^{\mathrm{A}}$ & $88.00^{\mathrm{A}-\mathrm{E}}$ & $33.00^{\mathrm{AB}}$ \\
\hline $\mathrm{GA}_{3}(500 \mathrm{ppm})+\mathrm{KNO}_{3}(0.2 \%)$ & $81.16^{\mathrm{AB}}$ & $31.33^{\mathrm{AB}}$ & $92.67^{\mathrm{AB}}$ & $32.67^{\mathrm{AB}}$ \\
\hline $\mathrm{GA}_{3}(500 \mathrm{ppm})+\mathrm{KNO}_{3}(0.3 \%)$ & $92.00^{\mathrm{A}}$ & $30.67^{\mathrm{A}}$ & $95.00^{\mathrm{A}}$ & $31.33^{\mathrm{A}}$ \\
\hline $\mathrm{GA}_{3}(1000 \mathrm{ppm})+\mathrm{KNO}_{3}(0.1 \%)$ & $77.33^{\mathrm{AB}}$ & $35.67^{\mathrm{C}-\mathrm{F}}$ & $90.33^{\mathrm{A}-\mathrm{D}}$ & $33.67^{\mathrm{A}-\mathrm{C}}$ \\
\hline $\mathrm{GA}_{3}(1000 \mathrm{ppm})+\mathrm{KNO}_{3}(0.2 \%)$ & $74.67^{\mathrm{A}-\mathrm{C}}$ & $34.33^{\mathrm{CD}}$ & $80.33^{\mathrm{EF}}$ & $34.33^{\mathrm{B}-\mathrm{D}}$ \\
\hline $\mathrm{GA}_{3}(1000 \mathrm{ppm})+\mathrm{KNO}_{3}(0.3 \%)$ & $82.61^{\mathrm{AB}}$ & $38.33^{\mathrm{FG}}$ & $76.67^{\mathrm{F}}$ & $37.00^{\mathrm{D}-\mathrm{F}}$ \\
\hline Kinetin $(250 \mathrm{ppm})$ & $90.67^{\mathrm{AB}}$ & $49.33^{\mathrm{K}}$ & $92.33^{\mathrm{AB}}$ & $42.67^{\mathrm{I}-\mathrm{K}}$ \\
\hline Kinetin $(500$ ppm) & $86.67^{\mathrm{AB}}$ & $42.00^{\mathrm{HI}}$ & $75.67^{\mathrm{F}}$ & $46.67^{\mathrm{KL}}$ \\
\hline Kinetin (1000 ppm) & $82.67^{\mathrm{AB}}$ & $52.67^{\mathrm{LM}}$ & $51.33^{\mathrm{H}}$ & $51.67^{\mathrm{M}}$ \\
\hline Thiourea $(0.5 \mathrm{M})$ & $46.67^{\mathrm{C}-\mathrm{E}}$ & $51.33^{\mathrm{K}-\mathrm{M}}$ & $32.33^{\mathrm{I}}$ & $49.33^{\mathrm{LM}}$ \\
\hline Thiourea $(1 \mathrm{M})$ & $21.67^{\mathrm{EF}}$ & $53.33^{\mathrm{MN}}$ & $19.67^{J}$ & $57.00^{\mathrm{N}}$ \\
\hline $\mathrm{H}_{2} \mathrm{SO}_{4}(1 \%) 30 \mathrm{sec}$. & $42.42^{\mathrm{DE}}$ & $37.67^{\mathrm{EF}}$ & $53.33^{\mathrm{H}}$ & $39.67^{\mathrm{F}-\mathrm{H}}$ \\
\hline $\mathrm{H}_{2} \mathrm{SO}_{4}(2 \%) 30 \mathrm{sec}$. & $58.67^{\mathrm{B}-\mathrm{D}}$ & $38.00^{\mathrm{FG}}$ & $58.67^{\mathrm{GH}}$ & $42.33^{\mathrm{H}-\mathrm{K}}$ \\
\hline $\mathrm{H}_{2} \mathrm{SO}_{4}(1 \%) 60 \mathrm{sec}$ & $88.00^{\mathrm{AB}}$ & $37.33^{\mathrm{EF}}$ & $84.67^{\text {B-F }}$ & $38.00^{\mathrm{E}-\mathrm{G}}$ \\
\hline $\mathrm{H}_{2} \mathrm{SO}_{4}(2 \%) 60 \mathrm{sec}$. & $68.33^{\mathrm{A}-\mathrm{D}}$ & $44.33^{\text {IJ }}$ & $64.00^{\mathrm{G}}$ & $48.00^{\mathrm{L}}$ \\
\hline
\end{tabular}


concentration (Oh et al., 2006; Finkelstein et al., 2008). A pre-chill applied at the appropriate time and for the proper duration did promote seed germination (Nkomo and Kambizi, 2009). In this study, pre-chilling improved germination up to $20 \%$ at T. scardica and $16 \%$ at T. $\mathrm{ko}$ sovarica, but again it was not a complete success. On the other hand, according to Amini et al. (2015), who studied the breaking dormancy of seeds of three foxtail species (Setaria glauca (L.) Beauv., S. verticillata (L.) P.Beauv. and S. viridis (L.) P.Beauv), reported that dry pre-chilling for 45 days have no significantly effect on seed germination of these species.

Exogenous application of $\mathrm{GA}_{3}$ in seeds of T. scardi$c a$ and T. kosovarica enhanced the seed germination. In this case, the highest germination percentage (FGP) and faster germination time (MGT) of seeds of both Tulipa species were detected in concentration of $500 \mathrm{ppm} \mathrm{GA}$ and $0.3 \% \mathrm{KNO}_{3}$. Moreover, it was significantly different to some treatments as shown with different letter (Table 2). The germination of the seeds of both Tulipa species decreased but not in significant level when increased the concentration of $\mathrm{KNO}_{3}, \mathrm{GA}_{3}$ and kinetin. In contrast with this, Rouhi et al. (2010) in Tulipa kaufmanniana seeds, reported that seeds soaked with $0.2 \%$ and $0.3 \% \mathrm{KNO}_{3}$ have greater germination than seeds treated with $0.1 \%$ $\mathrm{KNO}_{3}$. Previous research also confirmed that solutions with higher concentration of potassium nitrate have not significant effect on seed germination of Terminalia sericea Burch. ex DC (Amri et al., 2011) and Plantago ovata Forssk. (Ali et al., 2010). In the current research, it was revealed that lower concentration of potassium nitrate increased seed germination more than higher concentration. The positive effect of lower concentration of $\mathrm{KNO}_{3}$ could be related to its role of balancing seed hormones that results in the reduction of germination-inhibitors, like abscisic acid (Gashi et al., 2012).

The germination precentage in seeds of T. scardica and T. kosovarica, as indicated by decreased MGT, increased as the combination of $\mathrm{KNO}_{3}$ and $\mathrm{GA}_{3}$ increased, with greater effect of $500 \mathrm{ppm} \mathrm{GA}_{3}$ than $1000 \mathrm{ppm} \mathrm{GA}$ (Table 2). In this case, the best combination for the maximum germination ( $92 \%$ and $95 \%$, respectively) and the time of germination ( 30 and 32 days, respectively) was stratified seeds and treated with $500 \mathrm{ppm} \mathrm{GA}_{3}$ and $0.3 \%$ $\mathrm{KNO}_{3}$. Similar results were also reported for other Tulipa species, Rouhi et al. (2010) reported that the combination of $500 \mathrm{ppm} \mathrm{GA}$ and $0.1 \% \mathrm{KNO}_{3}$ was the best treatment for maximum germination (100\%) of seeds of Tulipa kaufmanniana. These results were also reported by Gashi et al. (2012) for Ramonda seeds. In addition, the best germination treatments for the seeds of Sabal palmetto (Walt.) Lodd. was combination with $1 \% \mathrm{KNO}_{3}$ and 500 ppm GA 3 (Dewir et al., 2011). In our study, higher concentration of $\mathrm{GA}_{3}(1000 \mathrm{ppm})$ did not increase the seed germination as well as lower concentration of $\mathrm{GA}_{3}(500$ or $250 \mathrm{ppm}$ ). In line with this, different plant species do not need a higher germination rate for enhanced germination or higher concentration can be as inhibitor of germination (Miransari and Smith, 2014; Finkelstein et al., 2008). On the other hand, Shanmugavalli et al. (2007), reported higher seed germination of sorghum treated with 1000 ppm GA. Additionaly, Amri et al. (2011), working on seeds of Terminalia sericea treated with $\mathrm{GA}_{3}$ $(400 \mathrm{ppm})$ confirmed higher percentage of germination (67\%) compared with control. According to Puttha et al. (2014), combination of pre-chilling with 500 ppm GA

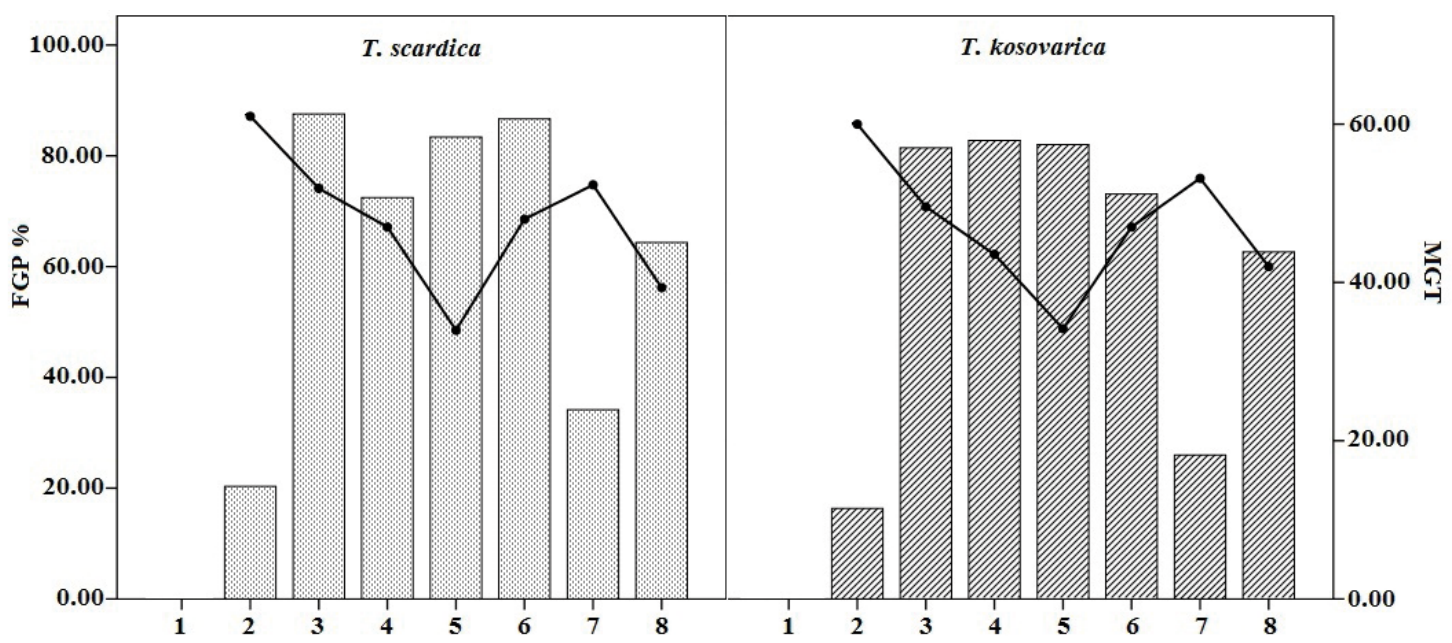

Figure 1: Mean of FGP and MGT of T. scardica and T. kosovarica. Each number from 1 to 8 shows the mean of different treatments: control (1); stratified seeds (2); seeds treated with different concentration of $\mathrm{KNO}_{3}(3), \mathrm{GA}_{3}(4), \mathrm{KNO}_{3}$ and GA3 (5), kinetin (6), thiourea (7), and $\mathrm{H}_{2} \mathrm{SO}_{4}(8)$ 


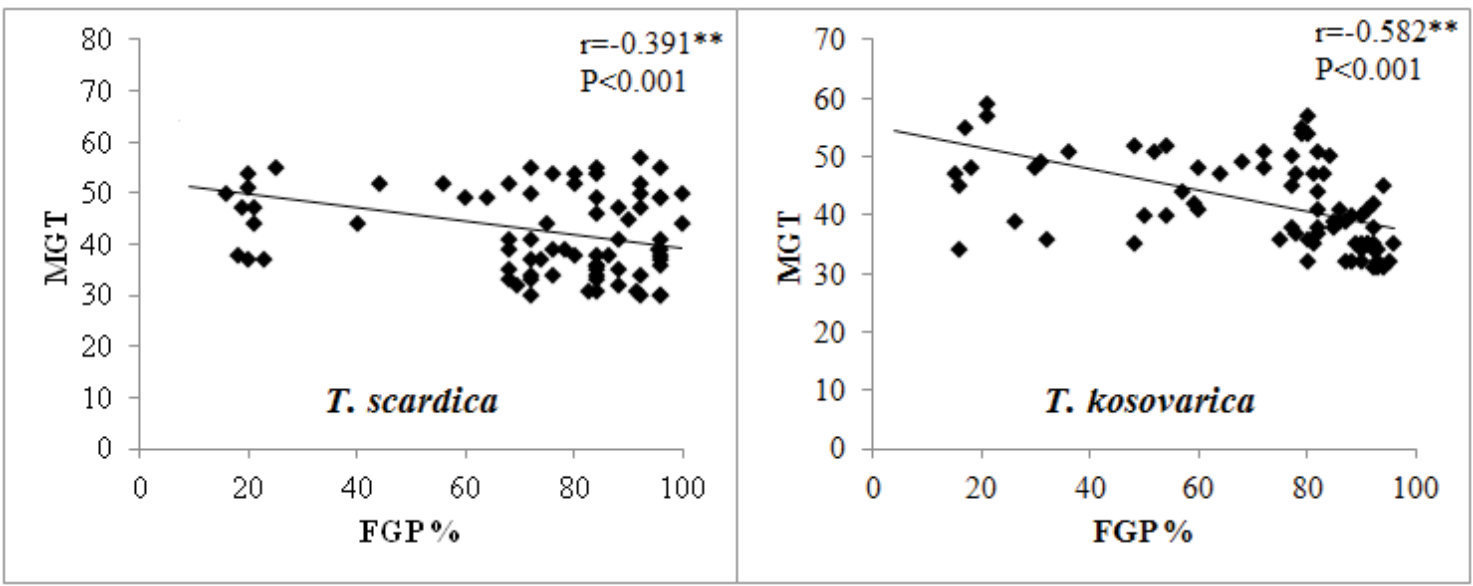

Figure 2: Correlation between MGT and FGP in seeds of T. scardica and T. kosovarica

was the best method for promoting germination seeds of Helianthus tuberosus L.. The results of this study for seeds requirement for pre-chilling and $\mathrm{GA}_{3}$ and $\mathrm{KNO}_{3}$ treatments for germination or breaking seed dormancy are in agreement with Zhang et al. (2006) and Li et al. (2007), who concluded that low temperature and $\mathrm{GA}_{3}$ treatments are necessary to release dormancy or increase seed germination.

The physiological role of $\mathrm{GA}_{3}$ as a germination promoter has been well known in the promotion of dormant seeds in a wide range of plant species as it induces hydrolytic enzymes (Miransari and Smith, 2014; Finkelstein et al., 2008) in order to overcome physiological dormancy in seeds with a dormant embryo (Baskin and Baskin, 2004). GA ${ }_{3}$ promotes seed germination by activating the synthesis of proteins and other required metabolites for the embryo.

Cytokinins are plants' hormones which are included to regulate various physiological processes in plant. Exogenous application of cytokinins has numerous effects on seed germination in different plants species. The cytokinins effect to enhance seed germination is mostly related to the alleviation of stresses from heavy metals, salinity, drought or oxidative stress (Khan et al., 2004; Nikolić et al., 2006). In this study, our results showed that seeds of T. scardica and T. kosovarica soaked with kinetin have significantly increased germination in comparison with control seeds and the lower concentration (250 ppm) of kinetin which has stronger effect on seed germination ( $90.67 \%$ and $92.33 \%$, respectively) than higher concentration. Previous investigation has reported that T. kosovarica seeds accumulated the $\mathrm{Ni}$ in their seeds (Osmani et al., 2018), and we can presume that these metals and other heavy metals which effect in these seeds can be alleviated by kinetin.

Among $\mathrm{H}_{2} \mathrm{SO}_{4}$ treatments, seeds of both Tulipa spe- cies were significantly enhanced of germination by $1 \%$ $\mathrm{H}_{2} \mathrm{SO}_{4}$ for 60 seconds seed treatment, in comparison with other concentration and duration time of this chemical. Treated seeds of both tulip species with thiourea have the lowest effect in FGP and MGT, but the lower concentration $(0.5 \mathrm{M})$ of thiourea had significant effect in comparison with higher concentration $(1 \mathrm{M})$.

Furthermore, the results of each seed treatment showed that more marked effects on the germination time (MGT) of seeds of T. scardica and T. kosovarica were observed when they were treated/germinated in combination with $\mathrm{KNO}_{3}$ and $\mathrm{GA}_{3}$ solutions (Figure 1). Depending on treatments, germination was in the range from $80 \%$ to $90 \%$ at both tulip species. Moreover, the maximum germination was detected in seeds treated with $\mathrm{KNO}_{3}, \mathrm{GA}_{3}$ and their combination, while the minimum germination in seeds without treatments and treated with thiourea (Figure 1).

Moreover, a negative significant association was established between MGT and FGP in seeds of T. scardica and T. kosovarica (Figure 2). This indicates that with the increase of the germination percentage, the time of germination shortened. Similar results were reported by Ganaie et al. (2011), who concluded that mean germination time was reduced and increased germination percentage was observed after seeds of Arnebia benthamii (Wall. ex G.Don) I.M.Johnst. were treated with different concentration of $\mathrm{KNO}_{3}$ and $25 \mathrm{ppm} \mathrm{GA}$. According to Ali et al. (2010), seeds of Descurainia sophia (L.) Webb ex Prantl and Plantago ovata treated with pre-chilling and $0.3 \%$ $\mathrm{KNO}_{3}$ showed significant differences of MGT in comparison with control seeds. 


\section{CONCLUSIONS}

The seeds of T. scardica and T. kosovarica plants have dormancy and the combined application of pre-chilling (stratification for 8 weeks) and plant growth regulators or some chemicals influence the seed dormancy breaking of these species. Among chemicals and plant growth regulators which were used in this research, the greater effect on seed germination have gibberellin, kinetin, and potassium nitrate. The highest seed germination percentage (FGP) and the speed of seed germination (MGT) of both Tulipa species were found in concentration of 500 ppm $\mathrm{GA}_{3}$ and $0.3 \% \mathrm{KNO}_{3}$.

The results of this study could contribute as an initial stage for propagation of these species for cultivation or propagation for commercial use as ornamental plants. On the other hand, propagation of these species could give an effective contribution to conservation or direct protection of these species, reducing damage by wild harvests and maintaining ex situ stocks of these threatened species in a secure and cost-effective manner.

\section{REFERENCES}

Alboresi, A., Gestin, C., Leydecker, M.T., Bedu, M., Meyer, C. \& Truong, H.N. (2005). Nitrate, a signal relieving seed dormancy in Arabidopsis. Plant, Cell and Environment, 28(4), 500-512. https://doi.org/10.1111/j.1365-3040.2005.01292.x

Ali, T., Hossein, P., Asghar, F. \& Salman, Z. (2010). The effect of different treatments on improving seed germination characteristics in medicinal species of Descurainia sophia and Plantago ovata. African Journal of Biotechnology, 9(39), 6588-6593.

Amini, V., Zaefarian, F. \& Rezvani, M. (2015). Effect of pre-chilling and environmental factors on breaking seed dormancy and germination of three foxtail species. Acta agriculturae Slovenica, 105 (2), 269-278. https://doi.org/10.14720/ aas.2015.105.2.10

Amri, E. (2011). Germination of Terminalia sericea Buch. Ex DC seeds: Effects of temperature regime, photoperiod, gebberellic acid and potassium nitrate. International Journal of Applied Biology and Pharmaceutical Technology, 2(2), 104110.

Baskin, J.M. \& Baskin, C.C. (2004). A classification system for seed dormancy. Seed Science Research, 14, 1-16. https://doi. org/10.1079/SSR2003150

Bewley, J.D. (1997). Seed germination and dormancy. The Plant Cell, 9, 1055-1066. https://doi.org/10.1105/tpc.9.7.1055

Dewir, Y.H., Mahrouk, M.E. \& Naido, Y. (2011). Effect of some mechanical and chemical treatments on seed germination of Sabal palmetto and Thrinax morrisii palms. Australian Journal of Crop Sciences, 5(3), 248-253.

Finch-Savage, W.E. \& Leubner-Metzger G (2006). Seed dormancy and the control of germination. New Phytologist, 171(3), 501-523. https://doi.org/10.1111/j.1469-8137.2006.01787.x
Finkelstein, R., Reeves, W., Ariizumi, T. \& Steber, C. (2008). Molecular Aspects of Seed Dormancy. Annual Review of Plant Biology, 59, 387-415. https://doi.org/10.1146/annurev.arplant.59.032607.092740

Ganaie, A.K., Aslam, S. \& Nawchoo, A.I. (2011). No chilling obligation for germination in seeds of Arnebia benthamii: A critically endangered alpine medicinal plant of north-west Himalayas. International Journal of Biodiversity and Conservation, 3(5), 155-159.

Gashi, B., Abdulla, K., Mata, V. \& Kongjika, E. (2012). Effect of gibberellic acid and potassium nitrate on seed germination of the resurrection plants Ramonda serbica and Ramonda nathaliae. African Journal of Biotechnolology, 11 (20), 45374542. doi: 10.5897/AJB12.009

Hermann, K., Meinhard, J., Dobrev, P., Linkies, A., Pesek, B., Hes, B., Machackova, I., Fischer, U. \& Leubner-Metzger, G. (2007). 1-Aminocyclopropane-1-carboxylic acid and abscisic acid during the germination of sugar beet (Beta vulgaris L.) - A comparative study of fruits and seeds. Journal of Experimental Botany, 58, 3047-3060. https://doi.org/10.1093/ jxb/erm 162

ISTA. (1996). Rules for Seed Testing. International Seed Testing Association. Seed Sci Technol. 24 suppl. Zürich, Switzerland.

KEPA. (2013). The red list of vascular flora of the Republic of Kosovo. Kosovo Environmental Protection Agency. Retrieved from http://www.ammk-rks.net/?page=1,23.

Khan, M.A., Gul, B. \& Weber, D.J. (2004). Action of plant growth regulators and salinity on seed germination of Ceratoides lanata. Canadian Journal of Botany, 82, 37-42. https://doi.org/10.1139/b03-140

Li, A.R., Guan,. K.Y. \& Probert, R.J. (2007). Effects of light scarification and gibberellic acid on seed germination of eight Pedicularis species from Yunnan, China. HortScience, 42, 1259-1262. https://doi.org/10.21273/HORTSCI.42.5.1259

Millaku, F. \& Elezaj, I. (2015). Tulipa luanica (Liliaceae), a new species from southern Kosovo. Annales Botanici Fennici, 52, 315-320. https://doi.org/10.5735/085.052.0506

Miransari, M. \& Smith, D.L. (2014). Plant hormones and seed germination. Environmental and Experimental Botany, 99, 110-121. https://doi.org/10.1016/j.envexpbot.2013.11.005

Moradi, D.P., Sharif-Zadeh, F. \& Janmohammadi, M. (2008). Influence of priming techniques on seed germination behavior of maize inbred lines (Zea mays L.). Journal of Agricultural and Biological Science, 3(3), 22-25.

Nikolić, R., Mitić, N., Miletić, R. \& Nešković, M. (2006). Effects of cytokinins on in vitro seed germination and early seedling morphogenesis in Lotus corniculatus L. Journal of Plant Growth Regulation, 25, 187-194. https://doi.org/10.1007/ s00344-005-0129-4

Nkomo, M. \& Kambizi, L. (2009). Effects of pre-chilling and temperature on seed germination of Corchorus olitorius L. (Tiliceas) (Jew's Mallow), a wild leafy vegetable. African Journal Biotechnology, 8, 1078-1081.

Oh, E., Yamaguchi, S., Kamiya, Y., Bae, G., Chung, W.I. \& Choi, G. (2006). Light activates the degradation of PIL5 protein to promote seed germination through gibberellin in Arabidopsis. The Plant Journal, 47, 124-139. https://doi. org/10.1111/j.1365-313X.2006.02773.x 
Osmani, M., Elezaj, I.R. \& Tuna, M. (2018). Concentration of some metals in soil and plant organs and their biochemical profiles in Tulipa luanica, T. kosovarica and T. albanica native plant species. Physiology and Molecular Biology of Plants, 24(6), 1117-1126. https://doi.org/10.1007/ s12298-018-0539-y

Puttha, R., Goggi, A.S., Gleason, M.L., Jogloy, S., Kesmala, T., Vorasoot, N., Bantemg, P., Patanothai, A. (2014). Pre-chill with gibberellic acid overcomes seed dormancy of Jerusalem artichoke. Agronomy for Sustainable Development, 34(4): 869-878. https://doi.org/10.1007/s13593-0140213-X

Rouhi, H.R., Shakarami, K. \& Afshari R.T. (2010). Seed treatments to overcome dormancy of waterlily tulip (Tulipa kaufmanniana Regel.). Australian Journal of Crop Science, 4(9), 718-721.

Shanmugavalli, M., Renganayaki, P.R. \& Menaka, C. (2007). Seed dormancy and germination improvement treatments in fodder sorghum. International Crops Research Institute Semi-Arid Tropics, 3, 1-3.

Shuka, L., Tan, K. \& Krasniqi, E. (2012). Tulipa kosovarica (Liliaceae), a new species of tulip from Kosovo. Phytotaxa, 62, 1-9. https://doi.org/10.11646/phytotaxa.62.1.1

Zhang, W.D., Bi, J.J., Ning, T.Y., Liu, G.S., He, M.R. (2006). Effect of temperature, light and other treatments on seed germination of Leymus chinensis. Canadian Journal of Plant Science, 86, 67-73. https://doi.org/10.4141/P04-125

Zhang, A., Jing, H., Yin, Ch. \& Li, G. (2010). Seed dormancy characteristics and germination condition of Tulipa gesneriana. Paracultural Science, 10, 1-10.

Zheng, C., Jiang, D., Liub, F., Dai, T., Liu, W., Jing, Q. \& Cao, W. (2009). Exogenous nitric oxide improves seed germination in wheat against mitochondrial oxidative damage induced by high salinity. Environmental and Experimental Botany, 67, 222-227. https://doi.org/10.1016/j.envexpbot.2009.05.002 